\title{
Defining critical success factors in TOD implementation using rough set analysis
}

\author{
Ren Thomas \\ University of Amsterdam \\ r.thomas@uva.nl
}

\author{
Luca Bertolini \\ University of Amsterdam \\ I.bertolini@uva.nl
}

\begin{abstract}
This paper defines critical success conditions in transitoriented development (TOD), evaluating the impact of practices, policies, and governance models on implementation. As part of a metaanalysis of 11 international case studies, 16 critical success factors were developed and validated using rough set analysis. The results show that political stability at the national level, relationships between actors in the region, interdisciplinary teams used to implement TOD, and public participation are the most significant success factors in TOD implementation. The set of decision rules reveals that several combinations of critical success factors have been effective in achieving implementation across city-regions in different contexts.
\end{abstract}

Keywords: case study, meta-analysis, transit-oriented development, policy transfer

\section{Introduction}

Transportation planners often look to international cases for policy measures and processes that have successful results, e.g., modal shift from car driving to public transit use, or implementation of a policy to concentrate development near railway stations. Learning from other cases often involves policy transfer (Marsden and Stead 2011; Spaans and Louw 2009), which may include copying policies directly, emulating the ideas behind the policy or program, or using the cases as inspiration for new unrelated policies (Dolowitz and Marsh 2000). Marsden and Stead (2001) note that local actors tend to look at examples within their own region or country, while national actors tend to look internationally since there may not be any relevant examples within the country.

Transit-oriented development (TOD) can be seen as a logical means toward compact urban development and sustainable transportation (public transit, cycling, and walking) to control growth and make efficient use of transportation infrastructure in urban regions. However, there are many complications in producing high-density, mixed-use developments in station areas or corridors served by adequate public transportation, biking, and walking infrastructure: The variety of actors, public and private institutions, and levels of government involved can make TOD difficult to implement. This is one reason why successful cases are often studied (e.g., Bertolini 1998; Cervero 1998; California Department of Transportation 2002; Cervero 2007; Curtis, Renne, and Bertolini 2009; Naess et al. 2011).

Copyright 2015 Ren Thomas \& Luca Bertolini

http://dx.doi.org/10.5198/jtlu.2015.513

ISSN: 1938-7849 | Licensed under the Creative Commons Attribution - Noncommercial License 3.0

The Journal of Transport and Land Use is the official journal of the World Society for Transport and Land Use (WSTLUR) and is published and sponsored by the University of Minnesota Center for Transportation Studies. This paper is also published with sponsorship from WSTLUR and the Institutes of Transportation Studies at the University of California, Davis, and the University of California, Berkeley. 
Case study is well established as a learning tool and research methodology in the discipline of planning, since it can integrate a variety of qualitative and quantitative methods and allow in-depth investigation into actors, processes, and institutions. However, single-case studies in particular do not provide planning departments and policymakers with generalizable findings to support them in policy development. Contextual issues can also act as a barrier to the implementation of key policies or programs in other jurisdictions.

A number of approaches can be used to address the "case study dilemma" (Thomas and Bertonlini 2014), including multiple-case studies and the choice of critical or atypical cases (e.g., Schofield 2002; Flyvberg 2001; Yin 1994). The next step in developing more generalizable research findings in transportation planning could be research that synthesizes completed case studies in an attempt to find common issues, concepts, or tools. This is the approach we have taken in this research, using the cross-case techniques of meta-matrices and rough set analysis.

This paper details the use of rough set analysis in a meta-analysis of 11 case studies of TOD implementation. The goal was to identify critical success factors (e.g., Nijkamp van der Burch, and Vindigni 2002; Van Egmond, Nijkamp, and Vindigni 2003) in TOD implementation to determine the practices, policies, and governance models that could work in The Netherlands. In the first phase of the study, we used meta-matrices to distill critical success factors (CSFs) in TOD implementation (Thomas and Bertolini 2014). In the second phase of the study, documented in this paper, a cross-case analysis of case study material and a web survey of local experts in the case cities tested these CSFs and contributed values to a codified data matrix. A rough set analysis was applied to this codified data matrix using ROSE2 software. The rough set analysis generated a series of rules that describe the relationships between the CSFs and performance measures, revealing how the factors contribute to successful TOD implementation.

The paper begins with a brief overview of the literature on TOD implementation. The CSFs, codified data matrix, and rough set analysis method are then discussed. Finally, the set of decision rules is presented, and possible applications to other municipalities and regions are discussed.

\section{Research background}

TOD can be described as the integration of land-use and transportation planning that makes walking, cycling, and transit use convenient and desirable, maximizing the efficiency of existing transit services by focusing development around transit stations, stops, and exchanges (TransLink 2012). TOD can be seen as part of a broader smart-growth approach to urban development including new urbanism, urban infill, urban growth boundaries, historic preservation, affordable housing, and inclusionary zoning (Knowles 2012). Bertolini, Curtis, and Renne $(2012,31)$ note that the TOD implementation approach in European cities has been evolving, possibly toward full-fledged embrace of American-Australian-style TOD by European cities, "an approach to station area projects which reaches further than single locations, and aims at the re-centering of entire urban regions around transport by rail and away from the car."

Based on the literature, the researchers used the following definition in this study:

TOD can be described as land-use and transportation planning that makes walking, cycling, and transit use convenient and desirable, and that maximizes the efficiency of existing public transit services by focusing development around public transit stations, stops, and exchanges. Successful TOD can be defined as implementation of this type of development at a regional scale.

There is a vast literature on TOD, particularly looking at successful cases. Here, we concentrate on the policies, practices, and governance models that seem to play a role in successful TOD implementa- 
tion. Curtis, Renne, and Bertolini (2009) tried to determine policies, practices, and governance models in international TOD cases that would be transferable to other cities and regions, including strong leadership, stakeholder and public engagement, a strategic transport land-use planning framework, publicprivate transit funding mechanisms, and efficient pricing of scarce resources. In a report summarizing TOD in California (California Department of Transportation 2002), successful implementation was found to rely on creative and effective public/private partnerships with active participation of all actors involved, multiple funding sources, and obtaining the support of key land-use and transportation planning civil servants early in the process. Cervero attempted "a variable-wise analysis within the framework of case-wise comparisons" (1998, 23), drawing lessons and insights from 12 cases by sorting them into four types and identifying similarities and differences within and across types. Among the lessons learned were the need for well-articulated visions for the future, inspired leadership, efficient institutions and governance, and flexible infrastructure and services.

Within this literature, and in our study, understanding the role of governance models focuses on understanding the roles of the public and private actors involved in the provision of public transportation (e.g., national railroad authorities, municipal and regional transportation departments, private companies contracted to provide transit services, transit users) and those involved in land development around transportation infrastructure (e.g., private developers, public land development authorities). Changing styles of governance (Howlett 2009) can also influence the implementation of TOD, including, for example, the shift from top-down, state-led transportation infrastructure projects to public-private arrangements where the private sector may propose developments within state-defined target areas.

Most studies that compare cases only focus on best practices. However, some authors have revealed barriers to TOD implementation (e.g., Curtis and Low 2012) through examination of less successful cases. Filion and McSpurren (2007) examined the shortcomings of policies aimed at integrating highdensity development with public transportation services in Toronto. One barrier to this integration was that planning interventions tend to be local rather than regional and are not consistent over a metro area for a long period of time:

Episodic and localized interventions are incapable of achieving the desired environmental objectives, in large part because they are unable to reshape behaviors in a way that conforms to these goals (Filion and McSpurren 2007, 503).

The lack of consistent planning policy at the regional level, and of a regional land-use authority, were also significant.

The above-mentioned studies do not explicitly address the issue of transferring lessons between different political and cultural contexts; Marsden and Stead (2011) note that there has been little attention to policy transfer in transportation planning. An exception is Stead, deJong, and Reinholde (2008); in a study of urban policy transfer in Central and Eastern Europe, this study describes Wroclaw, Poland, as having an early awareness of the role of public transit in the urban transportation system, so that policy-makers and civil servants were eager to adopt ideas to reduce car traffic and reverse a decline in public transit use. Wroclaw also had "the presence of forward-looking leadership among these officials, combined with relative political and administrative stability, which ensured that initiatives were not interrupted by other political parties taking office" (Stead, deJong, and Reinholde 2008, 67). Political and public support for public transit had increased during the period of policy transfer. The study also found that a small, closely-knit network of actors was extremely important in successful policy transfer.

While many studies have compared TOD cases, a systematic comparison of successful and unsuccessful cases with the goal of finding transferable policies, practices, and governance models has not yet been attempted. Sandelowski et al. $(1997,370)$ wrote that projects that aim to synthesize the findings of case studies should be recognized as an important avenue in knowledge development. Meta-analysis has 
been used for this purpose in other planning studies, e.g., public private partnerships (Nijkamp, van der Burch, and Vindigni 2002) and collaborative approaches to transportation projects (Walter and Scholtz 2007). These studies compare cases to find similarities, differences, and transferable lessons, and can be seen as attempts to develop more generalizable findings from case studies to aid in the development of theories and hypotheses. Further, Khan and VanWynsberghe (2008) proposed cross-case techniques "as a mechanism for mining existing case studies so that knowledge from cases can be put into service for broader purposes." A systematic comparison of international cases in TOD could be instrumental in developing knowledge in the area of implementation that could thfen be transferred to other political and cultural contexts.

\section{Data and methods}

Meta-analysis is one of many cross-case techniques (Miles and Huberman 1994) that can be used to enhance generalizability of case studies and deepen understanding and explanation. Meta-analysis aims to identify patterns and derive common elements from a set of case studies. Cases can then be compared, evaluated, and ranked on the basis of well-defined criteria or performance measures, and factors that are responsible for differing results across similar studies can be identified. Baaijens and Nijkamp (2001, 824) wrote that a major advantage of meta-analysis is "its ability to create scientific consensus on the underlying variation in findings from individual case studies." Another advantage is the ability to use completed case studies, resulting in a much shorter amount of time than that needed to gather primary data in a multiple-case study. Meta-analysis can integrate qualitative or quantitative data. Transferable lessons, or critical success factors (CSFs), can be distilled from cases regardless of whether or not they are considered successful according to performance measures. Variation in both critical success factors and performance measures reinforces the validity of the findings, showing not only what needs to be there but also how its absence affects outcomes.

Within meta-analysis, a number of techniques can be used to identify cross-case patterns, e.g., meta-matrices, qualitative metasynthesis (Schofield 1990), meta-regression (Gim 2012; Brons et al. 2005; Bamberg and Möser 2007), and rough set analysis (Baaijens and Nijkamp 2001). Meta-matrices can be used in a meta-analysis to allow the researcher to approach data (both qualitative and quantitative) in a systematic, transparent way; coded case data is entered into one or more tables and can be organized as needed by case or variable (Miles and Huberman 1994). The visual format allows the cases to be seen together, and the process of making the matrices, reorganizing the data according to timelines, and narrowing down the entries/categories helps develop explanations for the patterns. Meta-matrices can be particularly useful at an early stage of analysis as a way of organizing qualitative and quantitative data from the cases; they can reveal key attributes across cases. As a second stage in the meta-analysis, data can be refined into a codified data matrix, showing how each case rates using a variety of attributes.

Rough set analysis addresses two key difficulties in comparing case studies: cases often contain nominal or categorical values, and a case comparison typically uses fewer than 10 cases. This makes the use of many statistical methods problematic. In a comparison of completed planning projects, Nijkamp, van der Burch, and Vindigni $(2002,1867)$ wrote that, "the small sample size and the qualitative (often nominal or non-numerical) information on the performance of such projects" influenced its choice of rough set analysis as a methodological approach. The strength of rough set analysis is in the identification of deterministic rules supported by the categorically classified data available. This method can also incorporate the input of local experts to derive the rankings for each CSF in each case. Rules take the form of "if...then" statements ("decision rules") and reveal under which conditions a certain statement is valid. For the purposes of rough set analysis, the critical success factors are known as "attributes" of each case, and the performance measures are known as "decision attributes." 


\section{The use of meta-analysis in case comparison: Land use and transportation}

There have been several studies using meta-analysis to compare cases in land-use and transportation planning. Some transportation researchers have taken a purely quantitative approach to meta-analysis, selecting up to 75 cases by the presence of specific variables and data like time-based elasticities (Brons et al. 2005; Wardman 2012; Gim 2012; Bamberg and Möser 2007). These studies use meta-analysis as "an alternative, statistical approach to synthesising a body of quantitative research findings" (Bamberg and Möser 2007, 662), hence the larger number of cases used in their analyses and the use of meta-regression. Friman, Larhult, and Gärling (2013) compared policy programs by conducting means, standard deviations, and changes in trips per week. However, these studies do not aim to find transferable lessons and do not address the role of actors, institutions, and planning processes that are key to policy implementation. As Spaans and Louw (2009) notes, lesson-drawing focuses on a specific issue and is more practical than comparative research, which has a more scientific meaning because it aims to understand major differences and similarities in planning or spatial systems.

Nijkamp, van der Burch, and Vindigni (2002) used meta-analysis to identify critical success factors for urban development plans, using nine cases of public-private partnerships in urban revitalization and transformation projects. Van Egmond, Nijkamp, and Vindigni (2003) used meta-analysis to compare the public transportation systems in 22 European cities, using case reports, relevant documents, and data gathered in a systematic way by local experts in each city. The study aimed to identify whether a gradual transition toward a system of limited competition for urban public transport has been successful in achieving the transport agencies' stated targets. Walter and Scholtz (2007) did their cross-case comparison of collaborative urban transportation projects in five cities using reports, relevant documents, and interviews with local experts.

Van Egmond, Nijkanp, and Vindigni (2003) developed performance indicators based on official documents and local experts, who provided data in a systematic, uniform way to allow comparison. The degree of success was assessed using modal share as a performance measure (whether modal share of the system in each city was above or below the European average). Nijkamp, van der Burch, and Vindigni (2002) interprets success as a positive contribution from an executive and organizational perspective, an operational and marketing perspective, and a contractual and building perspective. A common assessment of the relative success scores of each project and its constituent facts was made based on interviews with stakeholders, administrative representatives, and local experts. Walter and Scholtz (2007) used efficiency, effectiveness, relevance, and the legitimacy of the process as performance measures. The performance indicators were assessed using an expert approach, while the critical success factors were assessed using interviews, publications, and reports.

Both Nijkamp, van der Burch, and Vindigni (2002) and Van Egmond, Nijkamp, and Vindigni (2003) used meta-matrices to consolidate data in the first phase of the meta-analysis, further refining it into quantitative form in a codified data matrix, then applied rough set analysis in the second stage. Software (such as ROSE2) extracts characteristic patterns from the codified data matrix, and determines decision rules from a set of examples. It evaluates the rules using validation techniques and constructs a knowledge representation in the form of decision rules, conditional statements that specify the conditions under which the statements are valid. Rough set analysis determines which attributes are most integral to success, and in which combinations.

Stefanowski (1998) describes two perspectives on developing rules in rough set analysis: classification, where the aim is to categorize cases; and discovery, where the goal is extracting previously unknown information patterns and regularities/exceptions. Three sets of rules are possible: the minimum set, 
which contains the smallest number of decision rules sufficient to describe all the cases; the exhaustive set, which contains all decision rules that can be generated from the given set of examples; and the satisfactory set, which contains only decision rules that can satisfy the user's requirements.

The satisfactory set of rules can lead to discovering a limited number of the strongest and the most general decision rules (Stefanowski 1998, 23).

Since our goal was discovery and we were particularly interested in the rules that could be most generalizable, we used ROSE2 software to find the satisfactory descriptive set of rules (e.g., Walter and Scholtz 2007) from the codified data matrix. This allowed us to set requirements for rule strength (the number of cases correctly classified divided by the total number of cases) and length (the number of conditions to be met). We set the strength at 75 percent (rules would apply to 75 percent of the cases) and the length at three (each rule would have at most three attributes). This means that the rules are approximately valid in at least 75 percent of the cases (i.e., their values do not exactly equal the values in the rule, but they do follow the rule), not only in the few cases where they are exactly valid (i.e., their values match the values in the rule perfectly).

\section{$5 \quad$ Critical success factors and codified data matrix}

City-regions, defined as the metropolitan area within which the majority of commuters travel, were chosen for this study because transportation planning is often conducted at a regional level or requires the cooperation of many local actors across the region. The case city-regions were chosen from a long list of possible international cases using the following criteria:

- Ample information was available on the transportation and land-use policies in the city-region (case study reports, original policy documents, and supporting academic literature)

- The city-region had been attempting to integrate transportation and land-use policy through TOD implementation for at least 20 years

- The authors were able to engage the help of three local experts for each case

City-regions that met these criteria were: Tokyo, Perth, Melbourne, Montreal, Vancouver, Toronto, Naples, Copenhagen, Amsterdam-Utrecht, Rotterdam-Den Haag, and Arnhem-Nijmegen. In metaanalysis the important criteria is that the cases are sufficiently similar in terms of the pursued goal, and the broader conditions allowing achievement of the goal (e.g., time); they should also be sufficiently different in terms of the measure in which the goal has been achieved, so that contributing factors can be identified. We deliberately chose cases that were similar in having pursued TOD for at least 20 years but different in the degree to which they were "successful" or "unsuccessful," according to the TOD definition given at the beginning of this paper.

Based on our definition of TOD, five performance measures (decision attributes) were used:

- Convenience and desirability of walking, cycling, and public transit

- Modal split (the combined share of walking, cycling, and public transit)

- Scale of implementation

- Maximizing efficiency of public transit infrastructure

- Overall success, an aggregate decision attribute incorporating the first four decision attributes

As described in (Thomas and Bertolini 2014), the creation of case reports, the process of coding the reports according to five categories, and entering coded data into the matrix served as a systematic method to recognize cross-case patterns. Data were re-ordered and configured according to timelines. At the bottom of each column containing the coded data from a single case, possible CSFs (attributes) were entered. These factors were a direct output of coding the data for practices, policies, and governance models; they were the common elements between cases. A listing of all the possible attributes was created and updated as further case study data were added to the matrix. In the end, 16 attributes were distilled from the meta-matrices (see Table 1). 
Table 1: Critical success factors

\begin{tabular}{|c|c|c|c|}
\hline \multicolumn{2}{|c|}{ Critical Success Factor } & Increases Success & Decreases Success \\
\hline \multicolumn{4}{|c|}{ Plans and Policies } \\
\hline 1 & Policy Consistency & $\begin{array}{l}\text { Very consistent over time in planning policy sup- } \\
\text { porting TOD, e.g., specific station areas, transit } \\
\text { corridors, and other transit-supportive and non- } \\
\text { motorized-supportive land-use planning }\end{array}$ & $\begin{array}{l}\text { Very inconsistent planning policy supporting } \\
\text { TOD, major changes over time }\end{array}$ \\
\hline 2 & Vision Stability & $\begin{array}{l}\text { Very stable vision, e.g., city-regional vision for land } \\
\text { use-transport planning or urban sustainability }\end{array}$ & Very unstable vision, major changes over time \\
\hline 3 & Government Support & $\begin{array}{l}\text { Very good support of higher levels of government, } \\
\text { e.g., provincial tax on gasoline to support public } \\
\text { transit, national station location or regeneration } \\
\text { policy, provincial funding for cycling infrastructure }\end{array}$ & $\begin{array}{l}\text { No support of higher levels of government, no } \\
\text { policies or funding }\end{array}$ \\
\hline 4 & $\begin{array}{l}\text { Political Stability } \\
\text { (National) }\end{array}$ & $\begin{array}{l}\text { Very stable national political agenda supporting } \\
\text { TOD }\end{array}$ & $\begin{array}{l}\text { Very unstable national political agenda sup- } \\
\text { porting TOD, major changes over time }\end{array}$ \\
\hline 5 & $\begin{array}{l}\text { Political Stability } \\
\text { (Local) }\end{array}$ & $\begin{array}{l}\text { Very stable local (municipal or regional) political } \\
\text { agenda supporting TOD }\end{array}$ & $\begin{array}{l}\text { Very unstable local (municipal or regional) } \\
\text { political agenda supporting TOD, major } \\
\text { changes over time }\end{array}$ \\
\hline \multicolumn{4}{|c|}{ Actors } \\
\hline 6 & Actor Relationships & $\begin{array}{l}\text { Very good relationships between municipal actors } \\
\text { at a regional scale, e.g., communication, overlap in } \\
\text { goals and vision, roles }\end{array}$ & $\begin{array}{l}\text { Poor or no relationships between municipal } \\
\text { actors at a regional scale }\end{array}$ \\
\hline 7 & $\begin{array}{l}\text { Regional Land Use- } \\
\text { Transportation Body }\end{array}$ & $\begin{array}{l}\text { Presence of a regulatory regional land use-transport } \\
\text { planning body }\end{array}$ & $\begin{array}{l}\text { No regional land use-transport planning body } \\
\text { (advisory or regulatory) }\end{array}$ \\
\hline 8 & $\begin{array}{l}\text { Inter-Municipal } \\
\text { Competition } \\
\end{array}$ & $\begin{array}{l}\text { No competition among municipalities for new } \\
\text { developments/funding }\end{array}$ & $\begin{array}{l}\text { Very intense competition among municipali- } \\
\text { ties for new developments/funding }\end{array}$ \\
\hline 9 & $\begin{array}{l}\text { Multidisciplinary } \\
\text { Implementation } \\
\text { Teams } \\
\end{array}$ & $\begin{array}{l}\text { Widespread presence of multidisciplinary teams } \\
\text { implementing TOD }\end{array}$ & $\begin{array}{l}\text { Sector-specific teams (e.g., solely planners or } \\
\text { engineers) implementing TOD }\end{array}$ \\
\hline 10 & Public Participation & $\begin{array}{l}\text { Very high public participation in land use-transport } \\
\text { planning processes }\end{array}$ & $\begin{array}{l}\text { No public participation, public not engaged } \\
\text { or interested }\end{array}$ \\
\hline 11 & Public Acceptance & $\begin{array}{l}\text { Very high public acceptance of high densities and } \\
\text { public transit }\end{array}$ & $\begin{array}{l}\text { No public acceptance of high densities and } \\
\text { public transit }\end{array}$ \\
\hline 12 & Key Visionaries & $\begin{array}{l}\text { Many influential key visionaries over time, e.g., } \\
\text { elected, citizen, or business leaders }\end{array}$ & No key visionaries over time \\
\hline \multicolumn{4}{|c|}{ Implementation } \\
\hline 13 & $\begin{array}{l}\text { Site-Specific Plan- } \\
\text { ning Tools }\end{array}$ & $\begin{array}{l}\text { Widespread use of site-specific planning tools, e.g., } \\
\text { FAR bonuses, leasing of air rights, density targets }\end{array}$ & No use of site-specific tools \\
\hline 14 & $\begin{array}{l}\text { Regional-Level TOD } \\
\text { Planning }\end{array}$ & $\begin{array}{l}\text { Corridor-level planning, e.g., coordination of land } \\
\text { use and transport in widespread transit corridors }\end{array}$ & No corridor-level or station-area planning \\
\hline 15 & $\begin{array}{l}\text { Certainty for Devel- } \\
\text { opers }\end{array}$ & $\begin{array}{l}\text { High degree of certainty for developers, e.g., plans } \\
\text { and policies supporting higher densities, tools to } \\
\text { enable mixed uses at station areas, designation of } \\
\text { areas for development/transit corridors }\end{array}$ & $\begin{array}{l}\text { Uncertainty; developers are unaware of poli- } \\
\text { cies, tools and sites encouraging TOD }\end{array}$ \\
\hline 16 & $\begin{array}{l}\text { Willingness to } \\
\text { Experiment }\end{array}$ & $\begin{array}{l}\text { Actors are very willing to experiment with new } \\
\text { policies, practices, and tools }\end{array}$ & $\begin{array}{l}\text { Actors are unwilling to experiment with new } \\
\text { policies, practices, and tools }\end{array}$ \\
\hline
\end{tabular}


It became clear during the process of creating the meta-matrix that each city-region had its own strengths and weaknesses in the plans and policies, actors, and implementation of TOD. Using the meta-matrices and a web survey of the local experts, a codified data matrix was developed where each cityregion was given values for its attributes and decision attributes. In this way the researchers' assessment of all the cases based on existing case studies was combined with the individual assessments of local experts on their own city-regions. As in Nijkamp, van der Burch, and Vindigni (2002) and Walter and Scholtz (2007), this grounded the insights from the meta-matrices with additional in-depth knowledge from practicing and academic planners that may have been missing from the case reports and supporting literature. Conversely, the meta-matrices served to balance any potential insider-bias of the local experts.

The web survey described the attributes to the local experts and explained each option in the fivepoint scale in detail. Using this scale encouraged the local experts to be objective about their own cityregion; likewise, the researchers used this limited scale to assess all the cases. A summary of the five-point scale is shown in Table 2.

Table 2: Case attributes, performance measures, and codification scale

\begin{tabular}{|c|c|c|c|c|c|c|}
\hline \multicolumn{7}{|c|}{ Values } \\
\hline Att & ibutes & 1 & 2 & 3 & 4 & 5 \\
\hline \multicolumn{7}{|c|}{ Plans and Policies } \\
\hline 1 & Policy Consistency & $\begin{array}{l}\text { Very inconsistent/major } \\
\text { changes over time }\end{array}$ & $\begin{array}{l}\text { Mostly inconsistent/a lot of } \\
\text { changes over time }\end{array}$ & $\begin{array}{l}\text { No clear consistency/incon- } \\
\text { sistency }\end{array}$ & $\begin{array}{l}\text { Mostly consistent/a few } \\
\text { changes over time }\end{array}$ & $\begin{array}{l}\text { Very consistent/no major } \\
\text { changes over time }\end{array}$ \\
\hline 2 & Vision Stability & $\begin{array}{l}\text { Very unstable/major } \\
\text { changes over time }\end{array}$ & $\begin{array}{l}\text { Mostly unstable/a lot of } \\
\text { changes over time }\end{array}$ & $\begin{array}{l}\text { Some degree of change in } \\
\text { vision }\end{array}$ & $\begin{array}{l}\text { Mostly stable/a few changes } \\
\text { over time }\end{array}$ & $\begin{array}{l}\text { Very stable/no major } \\
\text { changes over time }\end{array}$ \\
\hline 4 & $\begin{array}{l}\text { Political Stability } \\
\text { (National) }\end{array}$ & $\begin{array}{l}\text { Very unstable/major } \\
\text { changes over time }\end{array}$ & $\begin{array}{l}\text { Mostly unstable/a lot of } \\
\text { changes over time }\end{array}$ & $\begin{array}{l}\text { Some degree of change } \\
\text { over time }\end{array}$ & $\begin{array}{l}\text { Mostly stable/a few changes } \\
\text { over time }\end{array}$ & $\begin{array}{l}\text { Very stable/no major } \\
\text { changes over time }\end{array}$ \\
\hline 5 & $\begin{array}{l}\text { Political Stability } \\
\text { (Local) }\end{array}$ & $\begin{array}{l}\text { Very unstable/major } \\
\text { changes over time }\end{array}$ & $\begin{array}{l}\text { Mostly unstable/a lot of } \\
\text { changes over time }\end{array}$ & $\begin{array}{l}\text { Some degree of change } \\
\text { over time }\end{array}$ & $\begin{array}{l}\text { Mostly stable/a few changes } \\
\text { over time }\end{array}$ & $\begin{array}{l}\text { Very stable/no major } \\
\text { changes over time }\end{array}$ \\
\hline 7 & $\begin{array}{l}\text { Regional Land Use- } \\
\text { Transport Body }\end{array}$ & $\begin{array}{l}\text { No regional land use- } \\
\text { transportation body }\end{array}$ & $\begin{array}{l}\text { Municipal land use-trans- } \\
\text { portation body }\end{array}$ & $\begin{array}{l}\text { Informal inter-municipal } \\
\text { land use-transportation } \\
\text { coordination } \\
\end{array}$ & $\begin{array}{l}\text { Regional land use-trans- } \\
\text { portation body with an } \\
\text { advisory function }\end{array}$ & $\begin{array}{l}\text { Regional land use-transpor- } \\
\text { tation body with a regula- } \\
\text { tory function }\end{array}$ \\
\hline 8 & $\begin{array}{l}\text { Inter-Municipal } \\
\text { Competition }\end{array}$ & $\begin{array}{l}\text { Very intense competition/ } \\
\text { very unequal distribution } \\
\text { of new developments/ } \\
\text { funding }\end{array}$ & $\begin{array}{l}\text { Intense competition/un- } \\
\text { equal distribution of new } \\
\text { developments/funding }\end{array}$ & $\begin{array}{l}\text { Some competition/unequal } \\
\text { distribution of new devel- } \\
\text { opments/funding }\end{array}$ & $\begin{array}{l}\text { Little competition/equal } \\
\text { distribution of new devel- } \\
\text { opments/funding }\end{array}$ & $\begin{array}{l}\text { No competition/very equal } \\
\text { distribution of new develop- } \\
\text { ments/funding }\end{array}$ \\
\hline 9 & $\begin{array}{l}\text { Interdisciplinary } \\
\text { Implementation } \\
\text { Teams } \\
\end{array}$ & $\begin{array}{l}\text { Sector-specific teams } \\
\text { (e.g., solely planners or } \\
\text { engineers) } \\
\end{array}$ & Mostly sector-specific teams & $\begin{array}{l}\text { Some sector-specific and } \\
\text { some interdisciplinary } \\
\text { teams }\end{array}$ & $\begin{array}{l}\text { A good number of interdis- } \\
\text { ciplinary teams }\end{array}$ & $\begin{array}{l}\text { Widespread presence of } \\
\text { interdisciplinary teams }\end{array}$ \\
\hline 12 & Key Visionaries & $\begin{array}{l}\text { No key visionaries over } \\
\text { time }\end{array}$ & $\begin{array}{l}\text { Very few key visionaries } \\
\text { over time }\end{array}$ & $\begin{array}{l}\text { Some key visionaries over } \\
\text { time }\end{array}$ & $\begin{array}{l}\text { A good number of } \\
\text { influential key visionaries } \\
\text { over time }\end{array}$ & $\begin{array}{l}\text { Many influential key vision- } \\
\text { aries over time }\end{array}$ \\
\hline
\end{tabular}


Table 2 continued

\begin{tabular}{|c|c|c|c|c|c|c|}
\hline \multicolumn{7}{|c|}{ Values } \\
\hline Attr & ibutes & 1 & 2 & 3 & 4 & 5 \\
\hline \multicolumn{7}{|c|}{ Implementation } \\
\hline 13 & Site-Specific Tools & $\begin{array}{l}\text { No use of site-specific } \\
\text { tools }\end{array}$ & $\begin{array}{l}\text { Use of site-specific tools in } \\
\text { a few key projects }\end{array}$ & $\begin{array}{l}\text { Use of site-specific tools in } \\
\text { a few municipalities }\end{array}$ & $\begin{array}{l}\text { Use of site-specific tools in } \\
\text { most municipalities }\end{array}$ & $\begin{array}{l}\text { Widespread use of site- } \\
\text { specific tools across the } \\
\text { region }\end{array}$ \\
\hline 14 & $\begin{array}{l}\text { Regional TOD } \\
\text { Planning }\end{array}$ & $\begin{array}{l}\text { No designation of higher } \\
\text { densities / coordination } \\
\text { of land use and transport } \\
\text { in station areas or transit } \\
\text { corridors }\end{array}$ & $\begin{array}{l}\text { Few instances of designa- } \\
\text { tion of higher densities/co- } \\
\text { ordination of land use and } \\
\text { transport in station areas or } \\
\text { transit corridors }\end{array}$ & $\begin{array}{l}\text { Designation of higher } \\
\text { densities/coordination of } \\
\text { land use and transport in } \\
\text { isolated station areas }\end{array}$ & $\begin{array}{l}\text { Designation of higher } \\
\text { densities / coordination of } \\
\text { land use and transport in } \\
\text { networked station areas }\end{array}$ & $\begin{array}{l}\text { Designation of higher densi- } \\
\text { ties / coordination of land } \\
\text { use and transport in several } \\
\text { transit corridors }\end{array}$ \\
\hline 15 & $\begin{array}{l}\text { Certainty for De- } \\
\text { velopers }\end{array}$ & $\begin{array}{l}\text { Uncertainty; developers } \\
\text { are unaware of policies, } \\
\text { tools, and sites encourag- } \\
\text { ing TOD }\end{array}$ & $\begin{array}{l}\text { Very little certainty; devel- } \\
\text { opers are not very aware } \\
\text { of policies, tools, and sites } \\
\text { encouraging TOD } \\
\end{array}$ & $\begin{array}{l}\text { Some degree of certainty; } \\
\text { developers are somewhat } \\
\text { aware of policies, tools, and } \\
\text { sites encouraging TOD }\end{array}$ & $\begin{array}{l}\text { Good degree of certainty; } \\
\text { developers are mostly aware } \\
\text { of policies, tools, and sites } \\
\text { encouraging TOD }\end{array}$ & $\begin{array}{l}\text { High degree of certainty; } \\
\text { developers are very aware } \\
\text { of policies, tools, and sites } \\
\text { encouraging TOD }\end{array}$ \\
\hline 16 & $\begin{array}{l}\text { Willingness to } \\
\text { Experiment }\end{array}$ & Unwilling to experiment & $\begin{array}{l}\text { Very little willingness to } \\
\text { experiment }\end{array}$ & $\begin{array}{l}\text { Some degree of willingness } \\
\text { to experiment }\end{array}$ & $\begin{array}{l}\text { Good degree of willingness } \\
\text { to experiment }\end{array}$ & Very willing to experiment \\
\hline \multicolumn{7}{|c|}{ Values } \\
\hline \multicolumn{2}{|c|}{$\begin{array}{l}\text { Performance } \\
\text { Measures } \\
\end{array}$} & 1 & 2 & 3 & 4 & 5 \\
\hline $1 \mathrm{a}$ & $\begin{array}{l}\text { Convenience and } \\
\text { Desirability* (public } \\
\text { transit) }\end{array}$ & $\begin{array}{l}\text { No public transit infra- } \\
\text { structure /no access to } \\
\text { public transit }\end{array}$ & $\begin{array}{l}\text { Very little public transit } \\
\text { infrastructure/poor access } \\
\text { to public transit }\end{array}$ & $\begin{array}{l}\text { Some public transit infra- } \\
\text { structure/average access to } \\
\text { public transit in some areas }\end{array}$ & $\begin{array}{l}\text { Good amount of public } \\
\text { transit infrastructure/good } \\
\text { access to public transit in } \\
\text { many areas }\end{array}$ & $\begin{array}{l}\text { Widespread public transit } \\
\text { infrastructure/excellent } \\
\text { access to public transit across } \\
\text { the region }\end{array}$ \\
\hline $1 b$ & $\begin{array}{l}\text { Convenience } \\
\text { and Desirability* } \\
\text { (cycling) }\end{array}$ & $\begin{array}{l}\text { No cycling infrastructure / } \\
\text { no safe access to cycling }\end{array}$ & $\begin{array}{l}\text { Very little cycling infra- } \\
\text { structure/somewhat unsafe } \\
\text { access to cycling }\end{array}$ & $\begin{array}{l}\text { Some cycling infrastruc- } \\
\text { ture/safe access to cycling in } \\
\text { some areas }\end{array}$ & $\begin{array}{l}\text { Good amount of cycling } \\
\text { infrastructure/safe access to } \\
\text { cycling in many areas }\end{array}$ & $\begin{array}{l}\text { Widespread cycling infra- } \\
\text { structure/very safe access to } \\
\text { cycling across the region }\end{array}$ \\
\hline $1 \mathrm{c}$ & $\begin{array}{l}\text { Convenience and } \\
\text { Desirability* (walk- } \\
\text { ing) }\end{array}$ & $\begin{array}{l}\text { No walking infrastructure/ } \\
\text { no safe access to walking }\end{array}$ & $\begin{array}{l}\text { Very little walking } \\
\text { infrastructure/not very safe } \\
\text { access to walking }\end{array}$ & $\begin{array}{l}\text { Some walking infrastruc- } \\
\text { ture/safe access to walking } \\
\text { in some areas }\end{array}$ & $\begin{array}{l}\text { Good amount of public } \\
\text { transit infrastructure/safe } \\
\text { access to walking in many } \\
\text { areas }\end{array}$ & $\begin{array}{l}\text { Widespread public transit } \\
\text { infrastructure/very safe } \\
\text { access to walking across the } \\
\text { region }\end{array}$ \\
\hline 2 & $\begin{array}{l}\text { Modal Split (public } \\
\text { transit, cycling, } \\
\text { walking com- } \\
\text { bined)** }\end{array}$ & $<25$ & $26-35$ & $36-45$ & $46-55$ & $>55$ \\
\hline 3 & $\begin{array}{l}\text { Maximizes Ef- } \\
\text { ficiency }\end{array}$ & $\begin{array}{l}\text { Not efficient/development } \\
\text { not focused around sta- } \\
\text { tions or corridors }\end{array}$ & $\begin{array}{l}\text { Not very efficient/little de- } \\
\text { velopment around stations } \\
\text { or corridors }\end{array}$ & $\begin{array}{l}\text { Some degree of efficiency/ } \\
\text { some development around } \\
\text { stations and corridors }\end{array}$ & $\begin{array}{l}\text { Efficient/focused develop- } \\
\text { ment around stations and } \\
\text { corridors }\end{array}$ & $\begin{array}{l}\text { Maximizes efficiency/devel- } \\
\text { opment very focused around } \\
\text { transit stations and corridors }\end{array}$ \\
\hline 4 & $\begin{array}{l}\text { Scale of TOD } \\
\text { implementation }\end{array}$ & $\begin{array}{l}\text { No station areas, no public } \\
\text { transit corridors }\end{array}$ & $\begin{array}{l}\text { Only one main station area, } \\
\text { no public transit corridors }\end{array}$ & $\begin{array}{l}\text { A couple of station areas, } \\
\text { no public transit corridors }\end{array}$ & $\begin{array}{l}\text { Some station areas and } \\
\text { public transit corridors }\end{array}$ & $\begin{array}{l}\text { Many station areas, many } \\
\text { public transit corridors }\end{array}$ \\
\hline
\end{tabular}

Notes:

*Values for Performance Measures 1a, 1b, and 1c were averaged to give overall "convenience and desirability."

** Modal split values reflect the most recent values available for the city-regions. Public transit, cycling and walking mode shares were combined to give the level of non-car transportation. 
The codified data matrix in Table 3 represents an aggregate of the researchers' and local experts' assessment of the cases, with half of the weight given to the researchers' values and half to the local experts' values. The rough set analysis was applied to these aggregate values.

Table 3: Codified data matrix (for an explanation of the values, see Table 2)

\begin{tabular}{|c|c|c|c|c|c|c|c|c|c|c|c|c|}
\hline \multirow{2}{*}{\multicolumn{2}{|c|}{\begin{tabular}{|r} 
Attributes \\
Plans and Policies
\end{tabular}}} & TOK & PER & MEL & MON & VAN & TOR & NAP & COP & AMS & ARN & ROT \\
\hline & & \\
\hline 1 & Policy Consistency & 4 & 3 & 3 & 3 & 5 & 2 & 2 & 4 & 3 & 3 & 3 \\
\hline 2 & Vision Stability & 4 & 3 & 2 & 4 & 5 & 3 & 2 & 4 & 3 & 3 & 3 \\
\hline 3 & Government Support & 3 & 4 & 3 & 3 & 3 & 2 & 4 & 3 & 4 & 4 & 3 \\
\hline 4 & Political Stability (National) & 4 & 4 & 3 & 3 & 3 & 3 & 2 & 4 & 2 & 2 & 2 \\
\hline 5 & Political Stability (Local) & 4 & 4 & 3 & 3 & 4 & 2 & 2 & 5 & 2 & 3 & 3 \\
\hline \multicolumn{13}{|c|}{ Actors } \\
\hline 6 & Actor Relationships & 4 & 3 & 2 & 3 & 4 & 3 & 2 & 3 & 2 & 4 & 4 \\
\hline 7 & $\begin{array}{l}\text { Regional Land Use-Transport } \\
\text { Body }\end{array}$ & 3 & 4 & 1 & 3 & 4 & 3 & 2 & 2 & 1 & 4 & 4 \\
\hline 8 & Inter-Municipal Competition & 4 & 4 & 3 & 1 & 2 & 2 & 2 & 2 & 2 & 3 & 3 \\
\hline 9 & $\begin{array}{l}\text { Interdisciplinary Implementa- } \\
\text { tion Teams }\end{array}$ & 4 & 3 & 2 & 3 & 4 & 3 & 4 & 3 & 3 & 3 & 3 \\
\hline 10 & Public Participation & 2 & 4 & 3 & 3 & 5 & 3 & 2 & 2 & 1 & 3 & 2 \\
\hline 11 & Public Acceptance & 3 & 3 & 2 & 3 & 3 & 3 & 3 & 3 & 3 & 4 & 2 \\
\hline 12 & Key Visionaries & 2 & 4 & 1 & 4 & 4 & 3 & 3 & 2 & 2 & 3 & 3 \\
\hline \multicolumn{13}{|c|}{ Implementation } \\
\hline 13 & Site-Specific Tools & 5 & 3 & 2 & 4 & 5 & 3 & 2 & 3 & 1 & 2 & 2 \\
\hline 14 & Regional TOD Planning & 4 & 4 & 2 & 3 & 5 & 4 & 4 & 3 & 1 & 4 & 3 \\
\hline 15 & Certainty for Developers & 5 & 4 & 2 & 3 & 4 & 3 & 3 & 3 & 2 & 3 & 3 \\
\hline 16 & Willingness to Experiment & 5 & 4 & 2 & 4 & 4 & 3 & 3 & 3 & 2 & 4 & 4 \\
\hline \multicolumn{2}{|c|}{ Decision Attributes } & TOK & PER & MEL & MON & VAN & TOR & NAP & COP & AMS & ARN & ROT \\
\hline 1 & $\begin{array}{l}\text { Convenience and Desirability } \\
\text { of Walking, Cycling and Transit }\end{array}$ & 4 & 3 & 3 & 3 & 4 & 3 & 3 & 4 & 4 & 4 & 4 \\
\hline 2 & Modal Split & 5 & 1 & 1 & 2 & 2 & 2 & 3 & 4 & 3 & 3 & 2 \\
\hline 3 & Scale of Implementation & 5 & 4 & 3 & 5 & 5 & 4 & 3 & 4 & 3 & 4 & 4 \\
\hline 4 & $\begin{array}{l}\text { Maximizing Efficiency of Public } \\
\text { Transit Infrastructure }\end{array}$ & 5 & 3 & 2 & 4 & 3 & 4 & 3 & 3 & 3 & 3 & 3 \\
\hline 5 & Overall Success & 5 & 3 & 2 & 4 & 4 & 3 & 3 & 4 & 3 & 4 & 3 \\
\hline
\end{tabular}

Note: TOK=Tokyo, PER=Perth, MEL=Melbourne, MON=Montreal, VAN=Vancouver, TOR=Toronto, NAP=Naples, $\mathrm{COP}=$ Copenhagen, $\mathrm{AMS}=$ Amsterdam-Utrecht, $\mathrm{ARN}=$ Arnhem-Nijmegen, ROT=Rotterdam-Den Haag

The codified data matrix itself shows some interesting trends. The decision attributes show that only one of the cases was considered to have a very high overall success in TOD implementation, and four have a high overall success. On the other hand, only one of the cases was considered to have a low level of overall success, and none were ranked very low. One general finding, then, is that completely successful TOD implementation at the regional scale is rare, as is outright failure (at least when cases are chosen with our selection criteria). Looking at the decision attributes, we can see a breakdown of this success, with one case having a very high scale of implementation but a low modal split, another having a low modal split but high efficiency of public transit infrastructure, and so on. In other words, each case had strengths and weaknesses, and each took a different path to success. Some of these paths can be easily discerned by looking at the codified data matrix. However, there is no single attribute that seems to be responsible for high values in the decision attributes. Clearly, success or failure in TOD implementation depends on multiple factors, and the combinations of these factors cannot be easily understood from Table 3. It is here that rough set analysis can help. 


\section{Research results}

Overall, looking at the frequency of the attributes in the satisfactory descriptive rule set, we find that those with the highest frequency are political stability (national), regional land use-transportation body, relationships between actors in the region, public participation, interdisciplinary implementation teams, and certainty for developers.

Table 4: Rough set decision rules for all performance measures

\begin{tabular}{|c|c|c|c|}
\hline $\begin{array}{c}\text { Decision } \\
\text { Attribute and } \\
\text { Rule }\end{array}$ & If attribute meets the condition... & Then decision attribute is... & Cases where rule strength is $100 \%$ \\
\hline \multicolumn{4}{|c|}{ a. Overall Success } \\
\hline \multicolumn{4}{|c|}{ No strong rules generated } \\
\hline \multicolumn{4}{|c|}{ b. Convenience and Desirability } \\
\hline \multicolumn{4}{|c|}{ No strong rules generated } \\
\hline \multicolumn{4}{|c|}{ c. Maximizing Efficiency } \\
\hline 1 & $\begin{array}{l}\text { Political Stability (National) }=3 \text { AND } \\
\text { Actor Relationships }=3\end{array}$ & Maximizing Efficiency $=4$ & MON, TOR \\
\hline 2 & $\begin{array}{l}\text { Political Stability (National) }=3 \text { AND } \\
\text { Regional LUT Body }=3\end{array}$ & Maximizing Efficiency $=4$ & MON, TOR \\
\hline 3 & $\begin{array}{l}\text { Political Stability (National) }=3 \text { AND } \\
\text { Interdisciplinary Teams }=3\end{array}$ & Maximizing Efficiency $=4$ & MON, TOR \\
\hline 4 & $\begin{array}{l}\text { Political Stability (National) }=3 \text { AND } \\
\text { Certainty for Developers }=3\end{array}$ & Maximizing Efficiency $=4$ & MON, TOR \\
\hline 5 & $\begin{array}{l}\text { Actor Relationships }=3 \text { AND Regional } \\
\text { LUT Body }=3\end{array}$ & Maximizing Efficiency $=4$ & MON, TOR \\
\hline 6 & $\begin{array}{l}\text { Actor Relationships=3 AND Public } \\
\text { Participation=3 }\end{array}$ & Maximizing Efficiency $=4$ & MON, TOR \\
\hline 7 & $\begin{array}{l}\text { Regional LUT Body=3 AND Interdisci- } \\
\text { plinary Teams }=3\end{array}$ & Maximizing Efficiency $=4$ & MON, TOR \\
\hline 8 & $\begin{array}{l}\text { Regional LUT Body=3 AND Public } \\
\text { Participation }=3\end{array}$ & Maximizing Efficiency $=4$ & MON, TOR \\
\hline 9 & $\begin{array}{l}\text { Regional LUT Body=3 AND Certainty } \\
\text { for Developers=3 }\end{array}$ & Maximizing Efficiency $=4$ & MON, TOR \\
\hline 10 & $\begin{array}{l}\text { Public Participation=3 AND Public } \\
\text { Acceptance }=3\end{array}$ & Maximizing Efficiency $=4$ & MON, TOR \\
\hline 11 & $\begin{array}{l}\text { Public Participation=3 AND Certainty } \\
\text { for Developers }=3\end{array}$ & Maximizing Efficiency $=4$ & MON, TOR \\
\hline \multicolumn{4}{|c|}{ d. Scale of Implementation } \\
\hline 1 & Actor Relationships $=2$ & Scale of Implementation $=3$ & MEL, NAP, AMS \\
\hline 2 & $\begin{array}{l}\text { Vision Stability=3 AND Regional } \\
\text { TOD }=4\end{array}$ & Scale of Implementation $=4$ & PER, TOR, ARN, ROT \\
\hline \multicolumn{4}{|l|}{ e. Modal Split } \\
\hline 1 & Interdisciplinary Teams=2 & Modal Split=1 & PER, MEL \\
\hline 2 & $\begin{array}{l}\text { Government Support=3 AND Willing- } \\
\text { ness to Experiment=4 }\end{array}$ & Modal Split=2 & MON, VAN \\
\hline 3 & $\begin{array}{l}\text { Political Stability (National) }=3 \text { AND } \\
\text { Public Acceptance }=3\end{array}$ & Modal Split $=2$ & MON, VAN, TOR \\
\hline 4 & $\begin{array}{l}\text { Government Support }=4 \text { AND Political } \\
\text { Stability }(\text { National })=2\end{array}$ & Modal Split=3 & NAP, AMS, ARN \\
\hline
\end{tabular}


When we used the decision attribute "overall success," no strong decision rules were found (that is, none of the rules applied to 75 percent of the cases and had fewer than three attributes). The same applied to "convenience and desirability."

When using "maximizing efficiency" as a decision attribute, 11 rules were found. Four of the rules indicate the importance of some level of political stability at the national level; two rules show the importance of at least an average level of communication/collaboration between the actors; three rules indicate that informal inter-municipal collaboration in regional land use-transport is an important attribute; and two rules highlight the importance of some level of public participation in transportation and land-use planning. Other important attributes shown in the rules are some use of interdisciplinary teams, certainty for developers, and public acceptance of higher densities and transit. A middle level of these attributes contributes to a city-region that shows some efficient development around transit stations and corridors, exemplified in Montreal and Toronto, but true for the majority of the cases.

When "scale of implementation" is used as a decision attribute, two rules were found. The first rule shows that very little communication/collaboration between the actors leads to only some level of TOD implementation (e.g., in a couple of station areas but not at the corridor or regional level). With some level of vision stability and designation of many high-density station areas and/or transport corridors, a higher scale of implementation is possible (as we see in Perth, Toronto, Arnhem-Nijmegen, and Rotterdam-Den Haag, where the rule is the strongest).

"Modal split" as a decision attribute generated four rules. The first concerns the low level of interdisciplinary teams (with mostly sector-specific teams being used in TOD implementation), which leads to a very low modal split in favor of public transit, cycling, and walking. Perth is possibly the best example of this. The three remaining rules show the importance of some level of government support and national political stability and a high degree of willingness to experiment with TOD policy and planning in achieving higher modal splits. Rules two and four suggest that government support is more crucial than political stability or willingness to experiment in achieving high non-car mode shares. However, one limitation with this finding is that we did not have access to modal shift over time for all of the cases; data availability varies considerably across international cases. Therefore, we used the most recent modal shares available for each city-region in our codified data matrix. This means that it was not possible to develop decision rules that tell us the attributes that are responsible for a modal shift toward the noncar modes; they can only tell us about the relationship between the attributes and absolute modal split.

The meta-analysis has revealed that there are generalizable cross-case patterns among international TOD cases, revealing transferable lessons in TOD implementation. Moreover, the rough set analysis has identified the most important attributes and, in the form of decision rules, the combinations that can be applied to achieve success. National political stability (national), regional land use-transportation body, relationships between actors in the region, public participation, interdisciplinary implementation teams, and certainty for developers were the attributes with the highest frequency in the decision rules. This is not surprising: Stead, deJong, and Reinholde (2008) noted the importance of political stability in public transportation initiatives, and in The Netherlands cities with more formal collaboration between transportation and land-use actors have made greater strides toward TOD. Public participation and dialogue in transportation planning processes can be seen to have a major impact on public support for TOD (e.g., Curtis 2008; Tan 2011). Cervero (1998) noted that efficient institutions and governance (e.g., regional coordination of public transit or clearly delineated roles for public and private sectors) led to effective transportation land-use planning.

Other attributes that were present in the decision rules include government support, willingness to experiment, public acceptance, and vision stability. Attributes that did not appear in any of the decision rules were policy consistency, inter-municipal competition, key visionaries, and site-specific planning 
tools. This is perhaps surprising, since many TOD cases mention the lack of site-specific planning tools as a barrier to TOD (e.g., Hartoft-Nielsen 2002; Tan 2009). Key visionaries have been noted in TOD cases (Cervero 1998; Allum 2003; Tan et al. 2011), as has policy consistency (Newman 1991; Knowles 2012). Since we set a condition that rules should apply to 75 percent of the cases, our analysis suggests that these factors may have contextual rather than general relevance.

Another observation is the near absence of very high or very low levels of success according to the decision attributes, as already mentioned and seen in Table 3. This can perhaps be linked to the use of a five-point scale for assessment. Local experts on the cases tended to score more attributes in the middle of this scale rather than at the high or low ends. Several codified data matrices were made: one with the experts' values, one with the researchers' values, and a third with the aggregate values where the experts' and the researchers' values were equally weighted. After applying rough set analysis to all three sets of values, the aggregate codified data matrix was chosen as the most representative of the cases, as it generated the fewest and strongest rules when using the satisfactory descriptive technique for rule generation (Stefanowski 1998). Nevertheless, this aggregate codified data matrix still did not have many values at the top and bottom of the scale. There was only one score of five (Tokyo) and four scores of four for overall success (Montreal, Vancouver, Copenhagen, and Arnhem-Nijmegen). Looking at another decision attribute, the scale of implementation, we can see that five cases scored a four. The decision rule tells us that vision stability and a regional approach to TOD were the most significant contributors to a high scale of implementation. Therefore, the aggregate codified data matrix revealed significant relationships between the attributes and decision attributes even though it contained few values from the high and low ends of the five-point scale. The number and strength of rules were similar to that found in other studies (e.g., Nijkamp, van der Burch, and Vindigni 2002; Walter and Scholtz 2007).

An important note is that the attributes and decision rules were dependent on the specific cases and data used in this case study; finding cases with very high or very low levels of success for every decision attribute proved to be difficult. The aim of meta-analysis is to enhance generalizability of case studies and deepen understanding and explanation. There is evidently much to be learned from "imperfect" success, or even failure, in TOD implementation at the regional scale. A study with similar goals, that is to uncover policies, practices, and governance models useful in achieving successful implementation, would likely achieve similar results; the attributes have been noted in other studies comparing TOD cases.

One limitation was our access to data on the modal shift in the city-regions over time. Ideally, we would have had access to this data for all the cases. Such data could be collected through a multiple-case study (e.g., Scheurer and Curtis 2013), if resources were available. However, meta-analysis depends on completed case studies; these are plentiful in planning research, but use a range of research approaches and data (e.g., modal share in a specific development, for the commute to work. or for all trips). Metaanalysis is a powerful way to synthesize what we have-completed case study reports—-to develop transferable lessons.

This study has important, and readily transferable, implications for land-use and transportation planning policy, for example, determining how low rankings for the 16 attributes could be improved in a given city-region. This was tested in the next phase of the research, where Dutch land-use and transportation planners ranked the current strengths and weaknesses in two of the city-regions (Amsterdam-Utrecht and Rotterdam-Den Haag) using the 16 attributes. In workshops, they decided which attributes could be strengthened to achieve successful TOD implementation at a regional scale and how this could be done. For example, they could try to strengthen actor relationships to achieve a higher scale of implementation, or they could combine stronger actor relationships with an attempt to develop a regional land use-transportation body (even an informal one) to maximize efficiency of infrastructure. In this way, local actors took these de-contextualized lessons and re-contextualized them to their own 
city-regions (Thomas and Bertolini, in press).

As Spaans and Louw (2009) notes, there are limits to policy transfer. Some of these lessons may serve as learning and inspiration rather than direct transplantation. Grin (2010) notes that these instances of learning may contribute to profound structural change depending on the interaction between networks, rules, resources, actor relationships, and practices. Currently the integration of land use and transportation in The Netherlands has some conditions of uncertainty (e.g., the economic and financial crisis, absence of a scientific and political consensus on TOD, weak regional governance institutions, the new problem of surplus office space, and a mismatch between supply and demand of areas for residential development), which has influenced policy makers to look to other countries to develop implementation solutions (Stone 1999). Drawing lessons from other contexts can occur at the same time as policy development and coordination (Stone 1999); thus the transferable lessons need not replace any innovations in TOD implementation unique to the host country.

\section{Conclusions}

This study aimed to identify critical success factors in TOD implementation. Policy transfer has become increasingly important as city-regions attempt to develop innovative solutions to urban growth and sustainable transportation; defining transferable lessons in TOD implementation is useful in this context. The meta-analysis has proven successful in distilling CSFs, testing them, and revealing which combinations have worked toward regional TOD implementation. Those with the highest frequency are political stability (national), regional land use-transportation body, relationships between actors in the region, public participation, interdisciplinary implementation teams, and certainty for developers. Local land-use and transportation planners could apply these findings directly in their own city-regions, emulate the ideas behind the policies, practices, and governance models, or simply use them as inspiration to develop their own paths to success. The final stage of the research investigated this process in The Netherlands.

In addition to these findings, the study has shown that the use of meta-analysis provides researchers with the means to compare completed case studies in order to enhance generalizability and reliability. In the field of planning, this finding is significant because of the widespread use of case study as a research method and the prevalence of case study reports as potential sources of data. Going beyond the examination of TOD success stories, the meta-analysis method shows that both "success" and "failure" outcomes are useful in understanding the paths to successful implementation. 


\section{References}

Baaijens, S., and P. Nijkamp. 2001. Meta-analytic methods for comparative and exploratory policy research: An application to the assessment of regional tourist multipliers. Journal for Policy Modeling 22(7): 821-858.

Bamberg, S., and G. Möser. 2007. Why are work travel plans effective? Comparing conclusions from narrative and meta-analytical research synthesis. Transportation 34: 647-666.

Bertolini, L. 1998. Station area redevelopment in five European countries: An international perspective on a complex planning challenge. International Planning Studies 3(2): 163-184.

Bertolini, L., C. Curtis, and J. Renne. 2012. Station area projects in Europe and beyond: Towards transit oriented development? Built Environment 38(1): 31-50.

Brons, M., P. Nijkamp, E. Pels, and P. Rietveld. 2005. Efficiency of urban public transit: A meta- analysis. Transportation 32: 1-21.

California Department of Transportation. 2002. Statewide Transit-Oriented Development Study: Factors for Success in California. Caltrans: San Diego.

Cervero, R. 1998. The Transit Metropolis: A Global Inquiry. Washington, DC: Island Press.

Cervero, R. 2007. Transit-oriented development in the US: Contemporary practices, impacts and policy directions. In Incentives, Regulations and Plans: The Role of States and Nation-States in Smart Growth Planning, edited by G. J. Knaap, H. A. Haccou, K. J. Clifton, and J. W. Frece, 149-167. Cheltenham, UK: Edward Elgar Publishing.

Curtis, C. 2008. Evolution of the transit-oriented development model for low-density cities: A case study of Perth's new railway corridor. Planning, Practice and Research 23(3): 285-302.

Curtis, C., J. L. Renne, and L. Bertolini (Eds.) 2009. Transit Oriented Development: Making it Happen. USA and UK: Ashgate Publishing.

Curtis, C., and N. Low. 2012. Institutional Barriers to Sustainable Transport. USA and UK: Ashgate Publishing.

Dolowitz, D., and D. Marsh. 2000. Learning from abroad: The role of policy transfer in contemporary policy making. Governance 13 (1): 5-24.

Friman, M., L. Larhult, and T. Gärling. 2013. An analysis of soft transport policy measures implemented in Sweden to reduce private car use. Transportation 40: 109-129.

Flyvberg, B. 2001. Making Social Science Matter: Why Social Inquiry Fails and How it Can Succeed Again. Cambridge, UK: Cambridge University Press.

Gim, T. H. T. 2012. A meta-analysis of the relationship between density and travel behavior. Transportation 39: 491-519.

Grin, J. 2010. The governance of transitions. In Transitions to Sustainable Development: New Directions in the Study of Long Term Transformative Change, edited by J. Grin, J. Rotmans, and J. Schot, 265-285. New York and London: Routledge.

Khan, S. and R. VanWynsberghe. 2008. Cultivating the under-mined: Cross-case analysis as knowledge mobilization. Qualitative Social Research 9(1): article 34. http://www.qualitative-research.net/index. $\mathrm{php} / \mathrm{fqs} /$ article/view/334/729.

Knowles, R. D. 2012. Transit oriented development in Copenhagen, Denmark: From the finger plan to Ørestad. Journal of Transport Geography 22: 251-261.

Marsden, G., and D. Stead, 2011. Policy transfer and learning in the field of transport: A review of concepts and evidence. Transport Policy 19: 492-500.

Miles, M. B., and A. M. Huberman. 1994. Qualitative Data Analysis: An Expanded Sourcebook. Thousand Oaks, CA: Sage Publications. 
Naess, P., A. Strand, T. Naess, and M. Nicolaisen. 2011. On their road to sustainability? The challenge of sustainable mobility in urban planning and development in two Scandinavian capital regions. Town Planning Review 82(3): 285-315.

Newman, P. 1991. Toronto and Vancouver land use-transit success stories. Case Studies Index. Melbourne, Australia: Murdoch University. http://www.istp.murdoch.edu.au/ISTP/casestudies/Case_ Studies_Asia/canadian/canadian.html.

Nijkamp, P., M. van der Burch, and G. Vindigni. 2002. A comparative institutional evaluation of public-private partnerships in Dutch urban land-use and revitalization projects. Urban Studies 39: $1865-1880$.

Scheurer, J., and C. Curtis. 2013. Public transport accessibility in European and North American cities - a shared pursuit of best practice? Paper presented at the AESOP/ACSP Conference, July 2013, Dublin.

Schofield, J. W. 1990. Increasing the generalizability of qualitative research. In Qualitative Inquiry in Education: The Continuing Debate, edited by E. W. Eisner and A. Peshkin, 201-232. New York: Teachers College Press.

Schofield, J. W. 2002. Increasing the generalizability of qualitative research. In The Qualitative Researcher's Companion, edited by A. M. Huberman and M. B. Miles. Sage Publications: Thousand Oaks, CA, 171-204.

Spaans, M., and E. Louw. 2009. Crossing borders with planners and developers and the limits of lessondrawing. In City Futures in a Globalizing World, 1-21. Madrid: University Rey Juan Carlos of Madrid.

Stead, D., M. deJong, and I. Reinholde. 2008. Urban transport policy transfer in Central and Eastern Europe. The Planning Review 44(172): 62-73.

Stone, D. 1999. Learning lessons and transferring policy across time, space, and disciplines. Politics 19(1): 51-59.

Tan, W. G. Z. 2009. Policy context of key transit-oriented projects for station locations within the Netherlands. Paper presented at TU Berlin, Center for Metropolitan Studies. When? Berlin.

Tan, W. 2011.NICIS KEI Case Study \#1: Perth, Western Australia.

Tan, W., L. Bertolini, and L. Janssen-Jansen. 2012. The role of implementation barriers and institutional incentives in transit-oriented development: The cases of Perth, Portland and Vancouver. Paper presented at the AESOP 26th Annual Congress, July 11-15, 2012, Ankara, Turkey.

Thomas, R., and L. Bertolini. 2014. Beyond the case study dilemma in urban planning. Urban Policy and Research 32(2): 219-237. doi: 10.1080/08111146.2014.882256.

Thomas, R., and L. Bertolini. In press. Policy transfer among planners in transit-oriented development. Town Planning Review.

TransLink. 2012. Transit-Oriented Communities Guidelines. Creating More Livable Places Around Transit in Metro Vancouver. TransLink: Vancouver.

Van Egmond, P., P. Nijkamp, and G. Vindigni. 2003. A comparative analysis of the performance of urban public transport systems in Europe. International Social Science Journal 55(176): 235-247.

Walter, A. I., and R. W. Scholz. 2007. Critical success conditions of collaborative methods: A comparative evaluation of transport planning projects. Transportation 34: 195-212.

Wardman, M. 2012. Review and meta-analysis of U.K. time elasticities of travel demand. Transportation 39: 465-490.

Yin, R. K. 1994. Case Study Research: Design and Methods (2nd ed.). Sage: Thousand Oaks, CA. 